\title{
ABBREVIATIONS USED IN THE TEXT
}

$\begin{array}{ll}\text { AAA } & \text { American Authors Authority } \\ \text { AFTRA } & \text { American Federation of Television and Radio Artists } \\ \text { ALA } & \text { Authors League of America } \\ \text { AMPAS } & \text { Academy of Motion Picture Arts and Sciences } \\ \text { AMPTP } & \text { Alliance of Motion Picture and Television Producers } \\ \text { CAC } & \text { Contract Adjustment Committee } \\ \text { CFA } & \text { Committee for the First Amendment } \\ \text { CSU } & \text { Conference of Studio Unions } \\ \text { DGA } & \text { Directors Guild of America } \\ \text { FCC } & \text { Federal Communications Commission } \\ \text { HUAC } & \text { House Un-American Activities Committee } \\ \text { HWM } & \text { Hollywood Writers Mobilization } \\ \text { IATSE } & \text { International Alliance of Theatrical Stage Employees } \\ \text { MBA } & \text { Minimum Basic Agreement } \\ \text { MCA } & \text { Music Corporation of America } \\ \text { MPAA } & \text { Motion Picture Association of America } \\ \text { MPAPAI } & \text { Motion Picture Alliance for the Preservation of American Ideals } \\ \text { MPPDA } & \text { Motion Picture Producers and Distributors of America } \\ \text { NLRB } & \text { National Labor Relations Board } \\ \text { OWI } & \text { Office of War Information } \\ \text { PGA } & \text { Producers Guild of America } \\ \text { RWG } & \text { Radio Writers Guild } \\ \text { SAG } & \text { Screen Actors Guild } \\ \text { SAG-AFTRA } & \text { Screen Actors Guild-American Federation of Television and } \\ \text { SP } & \text { Radio Artists } \\ \text { SWG } & \text { Screen Playwrights } \\ \text { TSW } & \text { Screen Writers Guild } \\ \text { TWA } & \text { The Screen Writer } \\ \text { WGA } & \text { Television Writers Association } \\ \text { WGAE } & \text { Writers Guild of America } \\ \text { WGAw } & \text { Writers Guild of America, West } \\ & \end{array}$



The Writers 
EPISODE 101

1 Baltımore Circuit Court, Pt 23: A jury trial in progress, a drug-involved homicide case Judge-Clıfford-Watkıns,-black-middle-aged, vaguely weaned, presidıng as a young prosecutor struggles to keep witnesses from backing up on their grand jury testımony. The second row of seats in the half-empty courtroom is filled with some rough-looking characters, all staring intently at the prosecution witnesses, who are clearly frightened. One of those in the second-row -- Stringy-Bell-1- is better-dressed, more studious-looking. He writes on a legal pad as each witness answers questions. The defendant is young, black, trying to look hard but clearly nervous. The jury is mostly black, as is the prosecutor. In the back of the room, a rumpled, worn Insh face stares at the proceedings impassively.

Prosecutor. "Mr. Mitchell, did you or did you not tell the grand jury.. "

Witness "I can't remember now. I don't know that I told anyone anything.. "

The witness looks up at the Bell twenty feet away Bell eyefucks him coolly, writes something on his pad. The rumpled Inshman exhales, gets up, leaves. On Judge Watkıns, watching him go.

2 State's attorney's office, Violent Cnmes Unit. We follow the Irishman into the office He greets the secretanes, moving toward the rear offices as if he owns the place. He sees another cop, also white, on the phone, his feet up on a prosecutor's desk. The Inshman nods, listens. His fellow detective is arguing with a contractor about the cost of pressure-treated lumber

The Irishman sits. His pager goes off. He scans the number, frowns

The other detectuve hangs up, looks to the Irishman

"Fuckıng thieves."

"You puttıng a deck up?"

"Not for eight thousand I'm not. Fuckung theves."

The detective picks up the phone again, ready to do battle. The Irishman interrupts him. "You talked to Hansen lately?"

"I'm with Hansen in Part 23 right now. The Marando Bennett case "

"I know that I was just in there."

"Yeah?" asks the detective, not really giving a shit.

"Yeah. Your case is falling apart."

"The fuck it is"

The Irishman shrugs "Last two witnesses just backed all the way up."

"The fuck you say."

"You got Stringy Bell and his crew sitting in the second row staring them down They're backın' up like bad sewer pıpe."

"What's Hansen doing?"

The Irishman shrugs. The detective mulls the news over for a second, picks up the phone, calls a second contractor, seekıng another estımate

IMAGE 1 Summary notes on the pilot episode, "The Target," from David Simon's show bible for The Wire.

Show Bible Collection, Writers Guild Foundation Archive, Shavelson-Webb Library, Los Angeles 